\title{
A PRELIMINARY CENSUS OF THE MACROFUNGI OF MT WELLINGTON, TASMANIA - THE SEQUESTRATE SPECIES
}

\author{
by James M. Trappe, Neale L. Bougher, Michael A. Castellano, Andrew W. Claridge, Genevieve M. \\ Gates, Teresa Lebel and David A. Ratkowsky
}

(with one table and one appendix)

\begin{abstract}
Trappe, J.M., Bougher, N.L., Castellano, M.A., Claridge, A.W., Gates, G.M., Lebel, T. \& Ratkowsky, D.A. 2008: A preliminary census of the macrofungi of Mt Wellington, Tasmania - the sequestrate species. Papers and Proceedings of the Royal Society of Tasmania 142(1): 85-96. https://doi.org/10.26749/rstpp.142.2.85 ISSN 0080-4703. Department of Forest Ecosystems and Society, Oregon State University, Corvallis, Oregon 97331-5752, USA (JMT); Department of Environment and Conservation, Western Australian Herbarium, Locked Bag 104, Bentley Delivery Centre, Western Australia 6983, Australia (NLB); US Forest Service, Pacific Northwest Research Station, Forestry Sciences Laboratory, 3200 Jefferson Way, Corvallis, Oregon 97331, USA (MAC); Department of Environment and Climate Change, Parks and Wildlife Group, Southern Branch, PO Box 2115 , Queanbeyan, New South Wales 2620, Australia and School of Physical, Environmental and Mathematical Sciences, University of New South Wales, Australian Defence Force Academy, Northcott Drive, Canberra, Australian Capital Territory 2600, Australia (AWC); School of Plant Science, University of Tasmania, Private Bag 55, Hobart, Tasmania 7001, Australia (GMG); Royal Botanic Gardens Melbourne, Birdwood Avenue, South Yarra, Victoria 31 41, Australia (TL); School of Agricultural Science, University of Tasmania, Private Bag 54, Hobart, Tasmania 7001, Australia (DAR*). *Author for correspondence.
\end{abstract}

\begin{abstract}
This is the fourth and final contribution in a series of papers providing a preliminary documentation of the macrofungi of Mt Wellington, Tasmania. The earlier papers dealt with the gilled Basidiomycota, the non-gilled Basidiomycota and the Ascomycota, respectively, excluding the sequestrate species. The present paper completes the series by dealing with the sequestrate species, of which seven Ascomycota, 76 Basidiomycota, three Glomeromycota and one Zygomycota were found. Seven new genera and 25 new species, to be formally described elsewhere, are recorded.
\end{abstract}

Key Words: hypogeous, Ascomycota, Basidiomycota, Glomeromycota, Zygomycota, earthballs, truffles, truffle-like fungi.

\section{INTRODUCTION}

Earlier papers in this preliminary census of the Mt Wellington macrofungi concerned the gilled fungi (Ratkowsky \& Gates 2002), the non-gilled Basidiomycota (Gates \& Ratkowsky 2004) and the Ascomycota (Gates \& Ratkowsky 2005), but in each case the sequestrate species (commonly referred to as "earthballs" if Basidiomycota and "truffles" if Ascomycota) were ignored. This paper completes the series by dealing with the validly published sequestrate species that have been found and identified on Mt Wellington. Also included are some new genera and new species (shown in bold type in appendix 1) that are being described elsewhere. Nomenclature of the previously described species generally follows the two published volumes of the catalogue and bibliography of Australian fungi (May \& Wood 1997, May et al. 2003), with several exceptions.

The history of the earliest collections and study of sequestrate fungi in Australia has been detailed by Lebel \& Castellano (1999). In Tasmania, R.C. Gunn included fungi amongst his numerous botanical collections made between 1832 and 1850 and sent to the Royal Botanic Gardens, Kew. The Reverend M.J. Berkeley's contribution to the Flora Tasmaniae (Berkeley 1859) included species described from material sent by Gunn. The next major collector of Tasmanian fungi was the seemingly indefatigable L. Rodway, who, despite his training and official position in dentistry, became the (honorary) Government Botanist from 18921932, and included fungi amongst his numerous collections of plant groups from vascular plants to bryophytes. Unlike R.C. Gunn, who passed specimens on to a herbarium in the United Kingdom without describing or studying them, Rodway actively collaborated by correspondence with others, such as the Victoria-based plant pathologist D. McAlpine, the Kew-based G. Massee, the American mycologist C.G. Lloyd, and the South Australia-based J.B. Cleland. This active collaboration resulted in some joint publications (e.g., McAlpine \& Rodway 1896, Massee \& Rodway 1898), but Rodway frequently published alone (e.g., Rodway 1898, 1.912, 1918, 1920, 1921, 1924a, b, 1925a, b, 1926, 1929).

\section{MATERIALS AND METHODS}

Surveys for sequestrate species on Mt Wellington were carried out by the present authors and their co-workers at different times and in different groupings of collectors. For details of the survey zones used by G.M. Gates and D.A. Ratkowsky collecting jointly, see Ratkowsky \& Gates (2002), which includes a map of the survey area. The fieldwork is part of a continuing programme of surveys of macrofungi throughout Tasmania. During the period April 1998-August 2005, over 300 visits to Mount Wellington were made. Joint forays in various combinations of J.M. Trappe, M. Amaranthus, N.L. Bougher, M.A. Castellano, W. Colgan III, T. Lebel, N. Malajczuk and R. Robinson focused on sequestrate fungi on 2 and 7 May 1990, 17-18 May 1991, and 15 July 1993. In each of theseforays the participants fortuitously encountered good diversity and large numbers of fungi.

Trappe and Castellano have examined all of L. Rodway's sequestrate fungus rype collections from $\mathrm{Mt}$ Wellington as housed either at The Tasmanian Herbarium (HO) or the Royal Botanic Gardens, Kew, U.K. (K). Our descriptions of Rodway's species are based on his holotypes and expanded to reflect additional information from the new collections found 
in the forays noted above. Types of the new taxa found in our collections will be deposited at $\mathrm{HO}$ as they are published. Isotypes and other collections will be deposited in various other Australian herbaria, e.g., The Royal Botanic Gardens of Victoria (MEL), the Australian National Herbarium (CANB), and the Western Australian Herbarium (PERTH). Splits from collections with abundant specimens will also be deposited at K and the Mycological Herbarium of Oregon State University, USA (OSC). Representative material of previously described species is held in the private herbaria of the various authors, awaiting deposition in $\mathrm{HO}$ and other Australian herbaria.

Genera and species are listed alphabetically within each of the orders to which they were assigned by Hibbett $\&$. Binder (2006), Hosaka et al. (2006), Matheny et al. (2006), Miller et al. (2006) and Redecker \& Raab (2006) or as amended by recent work on the Australian sequestrate fungi. Nomenclature at the genus level in the Russulales follows that of Lebel \& Trappe (2000), Lebel \& Castellano (2002) and Lebel \& Tonkin (2007), and at the species level Lebel (2003a, b) and Lebel \& Tonkin (2007). For the cortinarioid sequestrate fungi, nomenclature at both genus and species level generally follows Francis \& Bougher (2002). Published photographs or drawings of species, where available, are cited after each description in appendix 1.

New taxa or new combinations not published by the time this paper is in press are cited by italicised and boldfaced letters of the alphabet, e.g., New genus $A$, new species $A$, etc. New genera appear at the end of the list for each order. Species that are to be transferred to another genus are listed under their present names but with comment on the intended new generic disposition.

\section{RESULTS}

Two orders of the sequestrate Ascomycota have been found on Mt Wellington: Elaphomycetales, with one genus and one species, and Pezizales, with five genera and six species. Gates \& Ratkowsky (2005) recorded 10 genera and 15 species of non-sequestrate Pezizales, more than twice as many as the sequestrate species.

The Mt Wellington sequestrate Basidiomycota are represented by six orders: Agaricales, with 12 genera and 29 species; Atheliales, with one genus and two species; Boletales, with six genera and seven species; Gomphales, with one genus and two species; Hysterangiales, with seven genera and 15 species; and Russulales, with six genera and 21 species for totals of 33 genera and 76 species. Thus, the sequestrate Basidiomycota of Mt Wellington contains five times more genera and nearly 11 times more species than the sequestrate Ascomycota.

The Glomeromycota are represented by two orders: Diversisporales, with one genus and one species, and Glomerales, with one genus and two species. The Zygomycota has only the order Endogonales with one genus and one species.

In all, seven new genera and 25 new species are represented in the Mt Wellington collections of sequestrate fungi.

\section{DISCUSSION}

Extensive collecting in southeastern mainland Australia has revealed a generally low proportion of sequestrate Ascomycetes to sequestrate Basidiomycota (Trappe, Claridge, Lebel \& Castellano unpubl. data). This trend also applies to $\mathrm{Mt}$ Wellington.

The epigeous, nonsequestrate, ectomycorrhizal genera of the Basidiomycota listed for Mt Wellington by Ratkowsky \& Gates (2002) and Gates \& Ratkowsky (2004) include Amanita, Cortinarius, Dermocybe and Descolea in the Agaricales; Boletellus, Boletus, Paxillus and Scleroderma in the Boletales; Ramaria in the Gomphales; and Lactarius and Russula in the Russulales, in all containing 36 species. The 74 hypogeous, sequestrate species listed in appendix 1 for the sequestrate relatives of these orders plus the Hysterangiales (not represented by any epigeous, nonsequestrate species) thus total more than twice as many species as the ectomycorrhizal, epigeous, nonsequestrate genera. Diversification of hypogeous species related to their epigeous ancestors at $\mathrm{Mt}$ Wellington is particularly striking for the epigeous Cortinariaceae and Russulaceae (table 1). This probably reflects the evolutionary climatic selection pressure of warm, dry weather and recurring drought so often common during the mushroom fruiting season in Australia (Trappe \& Claridge 2005), which in turn may account for the estimate that Australia has produced about one-third of the world's hypogeous, sequestrate fungal species (Mueller et al. 2006). A large number of undescribed Cortinarius species not included in the survey results of Ratkowsky \& Gates (2002) and Gates \& Ratkowsky (2004) occurs on Mt Wellington (Gates \& Ratkowsky unpubl. data). Given the relatively short collecting time devoted to hypogeous

TABLE 1

Numbers of epigeous, nonsequestrate, ectomycorrhizal species of Cortinarius, Descolea, Lactarius and Russula reported by Ratkowsky \& Gates (2002) and Gates \& Ratkowsky (2004) and their related, hypogeous, sequestrate species of the order Agaricales at Mt Wellington

\begin{tabular}{lclll}
\hline \multicolumn{2}{c}{ Epigeous taxa } & & Hypogeous taxa \\
\cline { 1 - 2 } Genus & $\begin{array}{c}\text { Number of } \\
\text { species }\end{array}$ & & Genera related to epigeous genera & Number of \\
Cortinarius & 13 & Dermocybe, Protoglossum, Quadrispora, Thaxterogaster, Timgrovea, new genus A & 17 \\
Descolea & 2 & Descomyces & 5 \\
Lactarius & 3 & Arcangeliella, Gastrolactarius & 7 \\
Russula & 5 & Cystangium, Gymnomyces, Russula & 13 \\
Total & 23 & Total & 42 \\
\hline
\end{tabular}


fungi there, numerous additional hypogeous taxa probably remain to be discovered. The ratio of epigeous to hypogeous species will change as more collecting takes place, but the important result is the splendid diversity of both groups of macrofungi offered by Mt Wellington.

The nomenclature of sequestrate fungi, in common with that of epigeous fungi, has been fluid as evidence of phylogenetic relationships is continually uncovered. The fluidity of taxonomic concepts may be illustrated by an examination and discussion of a monograph (Cunningham 1944) devoted to the Australasian (defined as Australia and New Zealand) Gasteromycetes, considered at that time to be a subclass of the class Basidiomycetes. Of the five orders in that subclass, the one composed of anastomosing, persistent tramal plates lined with the hymenium, viz. the Hymenogastrales, which no longer exists, will be considered here. Part of the Hymenogastrales is now placed in the Agaricales, part in the Boletales, part in the Gomphales, part in the Hysterangiales and part in the Russulales (Matheny et al. 2006, Hibbett \& Binder 2006, Hosaka et al. 2006, Miller et al. 2006). In the treatment of Cunningham (1944), two genera are conspicuous by their scope, each of which includes some very disparate species. One of these, Hymenogaster $\mathrm{Vittad}$., contained spores ranging from being perfectly smooth to having a rugulose-areolate, verrucose, or strongly reticulated exospore. Although these sequestrate species are statismosporic, thereby preventing a spore print from being obtained, the spore colour as seen through a light microscope would show a gradation from hyaline to dark brown to purplish brown. The taxonomic position of most of the species considered to belong to Hymenogaster in Cunningham's treatment has been clarified by molecular phylogenetic analyses (Peintner et al. 2001, Matheny et al. 2006).

The species formerly placed in Hymenogaster we now variously assign to Descomyces Bougher \& Castellano, Hymenogaster Vittad., Protoglossum Massee, Thaxterogaster Singer, Timgrovea Bougher \& Castellano, and two new, undescribed genera (Genus A and B). Thaxterogaster and Protoglossum are considered by Peintner et al. (2002) to be synonyms of the mushroom genus Cortinarius. That decision, however, was based solely on an ITS phylogeny of a few more than 100 species of Cortinarius and related genera, including sequestrate forms. Many of the branches were poorly resolved; multigene analyses are now considered important for reliable phylogenies, and in some cases RNA polymerase II genes have proven more useful in delineating species of Cortinarius than ITS (Froslev et al. 2005). Cortinarius is estimated to contain as many as 2000 species worldwide (Kirk et al. 2001), but more than 4000 species names have been published for the genus (Frøslev et al. 2005). Cortinarius is poorly known in Australia; estimates of the total number of species and their phylogenetic relationships are presently impossible. Moreover, the genes involved in evolution of epigeous to sequestrate morphologies are unknown, so their influence on molecular phylogenetic placement of species is speculative. We regard subsuming all species of Thaxterogaster and other sequestrate members of the Cortinariaceae into the huge and poorly resolved genus Cortinarius as premature. Accordingly, for purposes of this paper we use the sequestrate generic names.

An analogous circumstance applies to certain stipitate but sequestrate, hypogeous relatives of Russula, being placed by some authors in Russula, by others in Macowanites. The two sequestrate 'Macowanites' species found at Mt Wellington have both been described and named as Russula spp.: we list them as they were published rather than make new combinations that might prove premature.

The second genus of the Hymenogastrales sensu Cunningham (1944) that has unacceptably disparate elements is Octaviania Vittad. As was the case with Cunningham's treatment of Hymenogaster, the range of spore colour and type of ornamentation is very large. Some of the species listed there are now considered better placed in Arcangeliella Cavara, Cystangium Singer \& A.H. Sm., Gastrolactarius J.M. Vidal, Gymnomyces Massee \& Rodway, Horakiella Castellano \& Trappe, Hydnangium Wallr. or Stephanospora Pat. Had Melzer's reagent been employed in Cunningham's day for studies of sequestrate species, the amyloid reaction obtained for Arcangeliella, Cystangium, Gastrolactarius and Gymnomyces spores would have readily separated them from the others, none of which is amyloid.

Recent molecular phylogenetic studies of an array of sequestrate genera formerly placed variously in the Boletales, Gomphales, Hymenogastrales, Phallales and Lycoperdales has revealed that greatly disparate macro- and micromorphologies cluster together in the new order Hysterangiales (Hosaka $e t$ al. 2006). Thus Austrogautieria with ridged spores and a firm gleba, Hysterangium with smooth to minutely warty spores enclosed in a persistent utricle and a cartilaginous gleba, and the Australian endemic Mesophellia with smooth spores enclosed in an ephemeral utricle and a powdery spore mass in its gleba all fall into the Hysterangiales clade.

\section{ACKNOWLEDGEMENTS}

Trappe's participation in this study was supported in part by CSIRO Sustainable Ecosystems. Lebel and Trappe received support from Australian Biological Resources Study grants 95130 and 20650, Trappe and Castellano from U.S. National Science Foundation Grant BSR 9201421, and Trappe and Claridge from an Australian Biological Resources Study contract on a monograph of the hypogeous members of the Sclerodermatineae of Australia. M. Amaranthus, W. Colgan III, N. Malajczuk, R. Robinson and J. States generously contributed their Mt Wellington collections for our use. We are especially grateful to the personnel of $\mathrm{HO}$ and $\mathrm{K}$ for giving us access to Rodway's types, and to those herbaria as well as CANB, MEL, OSC and PERTH for accessioning our own collections.

\section{REFERENCES}

Beaton, G., Pegler, D.N. \& Young, T.W.K. 1984a: Gasteroid Basidiomycota of Victoria State, Australia: I. Hydnangiaceae. Kew Bulletin of Miscellaneous Information 39: 499-508.

Beaton, G., Pegler, D.N. \& Young, T.W.K. 1984́b: Gasteroid Basidiomycota of Victoria State, Australia: II. Russulales. Kew Bulletin of Miscellaneous Information 39: 669-698.

Beaton, G., Pegler, D.N. \& Young, T.W.K. 1985a: Gasteroid Basidiomycota of Victoria State, Australia: III. Cortinariales. Kew Bulletin of Miscellaneous Information 40: 167-204.

Beaton, G., Pegler, D.N. \& Young, T.W.K. 1985b: Gasteroid Basidiomycota of Victoria State, Australia: IV. Hysterangium. Kew Bulletin of Miscellaneous Information 40: 435-444.

Beaton, G., Pegler, D.N. \& Young, T.W.K. 1985c: Gasteroid Basidiomycota of Victoria State, Australia: V-VII. Boletales, Agaricales and Stephanosporaceae. Kew Bulletin 
of Miscellaneous Information 40: 573-598.

Beaton, G., Pegler, D.N. \& Young, T.W.K. 1985d: Gasteroid Basidiomycota of Victoria State, Australia: VIII-IX. Additional taxa. Kew Bulletin of Miscellaneous Information 40: $827-840$.

Beaton, G. \& Weste, G. 1977: The genus Labyrinthomyces. Transactions of the British Mycological Society 69: 243247

Beaton, G. \& Weste, G. 1978: The genus Sphaerozone. Transactions of the British Mycological Society 71: 164-167.

Beaton, G. \& Weste, G. 1982a: A new species of Scleroderma from Victoria, Australia. Transactions of the British Mycological Society 79: 41-43.

Beaton, G. \& Weste, G. 1982b: Australian hypogaean Ascomycetes. Transactions of the British Mycological Society 79: $455-468$.

Beaton, G. \& Weste, G. 1983: The genus Mesophellia in Victoria, Australia. Transactions of the British Mycological Society 80: $209-218$

Beaton, G. \&Weste, G. 1984: Victorian hypogaean Gasteromycetes: Mesophelliaceac. Transactions of the British Mycological Society 82: 665-671.

Berch, S.M. \& Fortin, A. 1983: Lectotypification of Glomus macrocarpum and proposal of new combinations: Glomus australe, Glomus versiforme, and Glomus tenebrosum (Endogonaceae). Canadian Journal of Botany 61: 2608-2617.

Berkeley, M.J. 1859: Fungi. In J.D. Hooker: The Botany of the Antarctic Voyage of H.M. Discovery Ships Erebus and Terror in the Years 1839-1843. Part III. Flora Tasmaniae. Vol. 2. Monocotyledones and Acotyledones. Lovell Reeve, London: 241-282.

Boedijn, K.B. 1939: The Tuberales of the Netherlands Indies. Bulletin du Jardin Botanique de Buitenzorg Série III 16: 236-244.

Bougher, N.L. \& Castellano, M.A. 1993: Delimitation of Hymenogaster sensu stricto and four new segregare genera. Mycologia 85: 273-293.

Bougher, N.L. \& Lebel, T. 2002: Australasian sequestrate (truffle-like) fungi. XII. Amarrendia gen. nov.: an astipitate, sequestrate relative of Torrendia and Amanita (Amanitaceae) from Australia. Australian Systematic Botany 15: 513-525.

Bougher, N.L. \& Malajczul, N. 1986: An undescribed species of hypogeous Cortinarius associated with Eucalyptus in Western Australia. Transactions of the British Mycological Society 86: 301-304

Bougher, N.L. \& Syme, K. 1998: Fungi of Southern Australia. University of Western Australia Press, Nedlands, W.A. $391 \mathrm{pp}$.

Bucholtz, F. 1912: Beiträge zur Kenntnis der Gattung Endogone Link. Beihefte zum Botanischen Centralblatt, Abt. 2, 29: 147-224.

Claridge, A.W. \& May, T.W. 1994: Mycophagy among Australian mammals. Australian Journal of Ecology 19: 251-275.

Claridge, A.W. \& Trappe, J. M. 2004: Managing habitat for mycophagous (fungus-feeding) mammals: a burning issue? In Lunney, D. (ed.): Conservation of Australia's Forest Fauna, $2^{\text {nd }}$ Edition. Royal Society of New South Wales, Sydney: 936-946.

Claridge, A.W., Trappe, J.M. \& Castellano, M.A. 200 I: Australasian truffle-like fungi. X. Gymnopaxillus (Basidiomycota, Austropaxillaceae). Australian Systematic Botany 14: 273-281

Cribb, J.W. 1958: The Gasteromycetes of Queensland - V. Octaviania and Hydnangium. University of Queensland Department of Botany Papers 3: 247-254.

Cunningham, G.H. 1932: The Gasteromycetes of Australasia, XV. The genera Mesophellia and Castoreum. Proceedings of the Linnean Society of New South Wales 57: 313-322.

Cunningham, G.H. 1934: The Gasteromyceres of Australasia,
XVI. Hymenogastraceae, Part I: the genera Rhizopogon, Melanogaster and Hymenogaster. Proceedings of the Linnean Society of New South Wales 59: 156-172.

Cunningham, G.H. 1938: The Gasteromycetes of Australasia, XVIII. Transactions of the Royal Society of New Zealand 67: $408-410$

Cunningham, G.H. 1944: The Gasteromycetes of Australia and New Zealand. John McIndoe, Dunedin, New Zealand (reprinted 1979, J. Cramer, Vaduz, Liechtenstein).

Dodge, C.W. \& Zeller, S.M. 1934: Hymenogaster and related genera. Annals of the Missouri Botanical Garden 21: 625-708.

Fischer, E. 1908: Zur Morphologie der Hypogaeen. Botanische Zeitung 66: 141-168.

Francis, A.A. \& Bougher, N.L. 2002 [2003]: Historical and current perspectives in the systematics of Australian cortinarioid sequestrate (truffle-like) fungi. Australasian Mycologist 21: 81-93.

Frøslev, T.G., Matheny, P.B. \& Hibbett, D.S. 2005: Lower level relationships in the mushroom genus Cortinarius (Basidiomycota, Agaricales): a comparison of RPB1, RPB2 and ITS phylogenies. Molecular Phylogenetics and Evolution 37: 602-618.

Gates, G.M. \& Ratkowsky, D.A. 2004: A preliminary census of the macrofungi of Mt Wellington, Tasmania - the nongilled Basidiomycota. Papers and Proceedings of the Royal Society of Tasmania 138: 53-59.

Gates, G.M. \& Ratkowsky, D.A. 2005: A preliminary census of the macrofungi of Mount Wellington, Tasmania - the Ascomycota. Papers and Proceedings of the Royal Society of Tasmania 139: 49-52.

Gilkey, H.M. 1954: Taxonomic notes on Tuberales. Mycologia 45: 783-793

Giachini, A.J., Oliveira, V.L., Castellano, M.A. \& Trappe, J.M. 2000: Ectomycorrhizal fungi in Eucalyptus and Pinus plantations in southern Brazil. Mycologia 92: 1166-1177.

Grgurinovic, C.A. 1997: Larger Fungi of South Australia. The Botanic Gardens of Adelaide and State Herbarium and the Flora and Fauna of South Australia Handbooks Committee, Adelaide: 725pp.

Hibbett, D.S. \& Binder, M. 2006: Molecular systematics and biological diversification of Boletales. Mycologia 98 971-981.

Hosaka, K., Bates, S.T., Beever, R.E., Castellano, M.A., Colgan III, W., Domínguez, L., Geml, J., Giachini, A.J., Kenney, S.R., Nouhra, E.R., Simpson, N.B., Spatafora, J.W. \& Trappe, J.M. 2006: Molecular phylogenetics of the gomphoid-phalloid fungi with an establishment of the new subclass Phallomycetidae and two new orders. Mycologia 98: 949-959.

Kirk, P.M., Cannon, P.F., David, J.C. \& Stalpers, J.A. $200 \mathrm{l}$ : Ainsworth and Bisby's Dictionary of the Fungi, $9^{\text {th }}$ Edition. CAB International, Wallingford, UK: 655 pp.

Lebel, T. 2003a: Australian sequestrate (truffle-like) fungi. XIII. Cystangium (Russulales, Basidiomycota). Australian Systematic Botany 16: 371-400.

Lebel, T. 2003b: Australian sequestrate (truffle-like) fungi. XIV. Gymnomyces (Russulales, Basidiomycota). Australian Systematic Botany 16: 401-426.

Lebel, T. \& Castellano, M.A. 1999: Australasian truffle-like fungi. IX. History and current trends in the study of the taxonomy of sequestrate macrofungi from Australia and New Zealand. Australian Systematic Botany 12: 803-817.

Lebel, T. \& Castellano, M.A. 2002: Type studies of sequestrate Russulales. II. Australian and New Zealand species related to Russula. Mycologia 94: 327-354.

Lebel, T. \& Tonkin, J.E. 2007: Australasian species of Macowanites are sequestrate species of Russula (Russulaceae, Basidiomycota). Australian Systematic Botany 20: $355-381$. 
Lebel, T. \& Trappe, J.M. 2000: Type studies of sequestrate Russulales. I. Generic type species. Mycologia 92: $1188-1205$.

Lloyd, C.G. 1922: Mycological Notes 67. Mycological Writings 7: 1137-1168.

Massee, G. \& Rodway, L. 1898: New hypogeous fungi from Tasmania. Kew Bulletin of Miscellaneous Information 138: 124-128.

Matheny, P.B., Curtis, J.M., Hofstetter, V., Aime, M.C., Moncalvo, J.-M., Ge, Z.-W., Yang, Z.-L., Slot, J.C., Ammirati, J.F., Baroni, T.J., Bougher, N.L., Hughes, K.W., Lodge, D.J., Kerrigan, R.W., Seidl, M.T., Aanen, D.K., DeNitis, M., Daniele, G.M., Desjardin, D.E., Kropp, B.R., Norvell, L.L., Parker, A., Vellinga, E.C., Vilgalys, R. \& Hibbett, D.S. 2006: Major clades of Agaricales: a multilocus phylogenetic overview. Mycologia 98: 982-995.

May, T.W. \& Wood, A.E. 1997: Catalogue and Bibliography of Australian Macrofungi 1. Basidiomycota p.p. (Fungi of Australia, Volume 2A). Australian Biological Resources Study, Canberra: 348 pp.

May, T.W., Milne, J., Shingles, S. \& Jones, R.H. 2003: Catalogue and Bibliography of Australian Fungi 2. Basidiomycota p.p. \& Myxomycota p.p. (Fungi of Australia, Volume 2B). Australian Biological Resources Study, Canberra: $452 \mathrm{pp}$.

McAlpine, D. \& Rodway, L. 1896: Australian fungi. Agricultural Gazette of New South Wales 7: 84-87.

McGee, P.A. \& Trappe, J.M. 2002: The Australian zygomycetous mycorrhizal fungi. 11. Further Australian sporocarpic Glomaceae. Australian Systematic Botany 15: 115-124.

Miller, S.L., Larsson, E., Larsson, K.-H., Verbeken, A. and Nuytinck, J. 2006: Perspectives in the new Russulales. Mycologia 98: 960-970.

Mueller, G.M., Schmit, J.P., Leacock, P.R., Buyck, B., Cifuentes, J., Desjardin, D.E., Halling, R.E., Hjortstam, K., Iturriaga, T., Larsson, K.-H., Lodge, D.J., May, T.W., Minter, D., Rajchenberg, M., Redhead, S.A., Ryvarden, L., Trappe, J.M., Watling, R. \& Wu, Q. 2006: Global diversity and distribution of macrofungi. Biodiversity and Conservation 16: 37-48.

Pegler, D.N. \& Young, T.W.K. 1979: The gasteroid Russulales. Transactions of the British Mycological Society 72: 353388.

Peintner, U., Bougher, N.L., Castellano, M.A., Moncalvo, J.-M., Moser, M. M., Trappe, J. M. \& Vilgalys, R. 2001: Multiple origins of sequestrate fungi related to Cortinarius (Cortinariaceae). American Journal of Botany 88: $2168-2179$.

Peintner, U., Moser, M. \& Vilgalys, R. 2002: Thaxterogaster is a taxonomic synonym of Cortinarius: new combinations and new names. Mycotaxon 81: 177-184.

Ratkowsky, D.A. \& Gates, G.M. 2002: A preliminary census of the macrofungi of Mount Wellington, Tasmania - the Agaricales. Papers and Proceedings of the Royal Society of Tasmania 136: 89-100.

Redecker, D. \& Raab, P. 2006: Phylogeny of the Glomeromycota (arbuscular mycorrhizal fungi): recent developments and new gene markers. Mycologia 98: 885-895.

Redecker, D., Raab, P., Oehl, F., Camacho, FJ. \& Courtecuisse, R. 2007: A novel clade of sporocarp-forming species of glomeromycotan fungi in the Diversisporales lineage. Mycological Progress 6: $35-44$.

Rodway, L. 1898: Underground fungi of Tasmania. Reports of the Meeting of the Australasian Association for the Advancement of Science 7: 488-493.

Rodway, L. 1912: The Hymenogastraceae of Tasmania. Papers and Proceedings of the Royal Society of Tasmania 1911: $21-31$.

Rodway, L. 1918: Botanical notes. Papers and Proceedings of the Royal Society of Tasmania 1917: 105-1 10.
Rodway, L. 1920: Notes and additions to the fungus flora of Tasmania. Papers and Proceedings of the Royal Society of Tasmania 1919: 110-116.

Rodway, L. 1921: Additions to the fungus flora of Tasmania, Part 3. Papers and Proceedings of the Royal Society of Tasmania 1920: $153-159$.

Rodway, L. 1924a: Description of two underground fungi. Papers and Proceedings of the Royal Society of Tasmania 1923: 108 .

Rodway, L. 1924b: Tasmanian Hymenogastraceae. Papers and Proceedings of the Royal Society of Tasmania 1923: 151-161.

Rodway, L. 1925a: Two interesting fungi. Papers and Proceedings of the Royal Society of Tasmania 1924: 8.

Rodway, L. 1925b: Tasmanian Discomycetes. Papers and Proceedings of the Royal Society of Tasmania 1924: 90-122.

Rodway, L. 1926: Notes on some rare and interesting cryptogams. Papers and Proceedings of the Royal Society of Tasmania 1925: $167-170$.

Rodway, L. 1929: Note on Gautieria in Tasmania. Papers and Proceedings of the Royal Society of Tasmania 1928: 72.

Singer, R. \& Smith, A.H. 1960: Studies on secotiaceous fungi IX. The asterogastraceous series. Memoins of the Torrey Botanical Club 21: 1-112.

Stewart, E.L. \& Trappe, J.M. 1985: The new genus Austrogautieria (Basidiomycotina), segregate from Gautieria. Mycologia 77: 674-687.

Thaxter, R. 1922: A revision of the Endogoneae. Proceedings of the American Academy of Arts and Sciences 57: 291-351.

Trappe, J.M. 1975: The genus Amylascus (Tuberales). Transactions of the British Mycological Society 65: 496-499.

Trappe, J.M. 1979: The orders, families, and genera of hypogeous Ascomycotina (truffles and their relatives). Mycotaxon 9 297-340.

Trappe, J.M., Castellano, M.A. \& Malajczuk, N. 1992: Australasian truffe-like fungi. II. Labyrinthomyces, Dingleya and Reddellomyces gen. nov. (Ascomycotina). Australian Systematic Botany 5: 597-611.

Trappe, J.M., Castellano, M.A. \& Malajczuk, N. 1996 Australasian truffle-like fungi. VII. Mesophellia (Basidiomycotina, Mesophelliaceae). Australian Systematic Botany 9: 773-802.

Trappe, J.M. \& Claridge, A.W. 2003: Australasian sequestrate (truffle-like) fungi. 15. New species from tree line in the Australian Alps. Australasian Mycologist 22: 27-38.

Trappe, J.M. \& Claridge, A.W. 2005: Hypogeous fungi: evolution of reproductive and dispersal strategies through interactions with animals and mycorrhizal plants. In Dighton, J., White, J.F. \& Oudemans, P. (eds): The Fungal Community - Its Organization and Role in the Ecosystem. Taylor \& Francis, Boca Raton, Florida: 613-623.

Trappe, J.M. \& Claridge, A.W. 2006: Australasian sequestrate (truffle-like) fungi. 17. Hydnoplicata convoluta, the 'bounced about' Australian truffle (Ascomycota, Pezizaceae). Australasian Mycologist 25: 33-35.

Tulasne, L.-R. \& Tulasne, C. 1851: Fungi Hypogaei. Friedrich Klincksieck, Paris (reprinted 1970, A. Asher \& Co., Vaals, The Netherlands).

White, N.H. 1956: A note on truffle fungi in Australia with special reference to Labyrinthomyces steenisii Boedijn. Transaction of the British Mycological Society 39: 341-342.

Zeller, S.M. \& Dodge, C.W. 1929: Hysterangium in North America. Annals of the Missouri Botanical Garden 16: 83-123.

Zhang, B.-C. \& Minter, D.W. 1988: Two new species of Labyrinthomyces from New Zealand, with notes on taxonomy of the genus. Systema Ascomycetum 7: 45-55.

Zhang, B.-C. \& Minter, D.W. 1989: Gymnohydnotrya: a new hypogeous ascomycete genus from Australia. Mycological Research 92: 192-198.

(accepted 4 November 2008) 


\section{APPENDIX 1}

\section{Species descriptions of Mt Wellington sequestrate fungi}

\section{ASCOMYCOTA}

\section{[Elaphomycetales]}

Elaphomyces new species $A$ - Fruit bodies $8-25 \mathrm{~mm}$ broad, subglobose, enclosed in golden brown, yellowish brown to orange brown mycelium with intermixed soil, debris and mycorrhizae. Peridium tough, frrm, with an outer layer of pyramidical warts $<0.5 \mathrm{~mm}$ tall, a middle layer forming a more or less uniformly dark line directly beneath the outer layer, and an inner layer grey to pale violet brown, rosy brown or brown. Gleba hollow in youth, soon filling with cottony ascogenous hyphae, at maturity filled with a black, powdery spore mass. Spores globose, (22-) 24-28 (-32) $\mu \mathrm{m}$ broad, including the ornamentation of coarse, flattened amorphous warts $4-5$ um tall.

\section{[Pezizales]}

Amylascustasmanicus (Rodway) Trappe - Up to $3 \mathrm{~cm}$ broad, chestnut brown, ridged and furrowed, minutely verrucose and tomentose, with a basal, hyphal attachment. Gleba of convoluted folds of tissue, penetrated with meandering veins and labyrinthine chambers up to $2 \mathrm{~mm}$ broad. Asci weakly but evenly blue in iodine solution. Spores globose, 20-26 $\mu \mathrm{m}$ broad including the ornamentation of hyaline rods and cones $1(-2) \mu \mathrm{m}$ tall and $0.5-1.5 \mu \mathrm{m}$ broad. Illustrations - Trappe (1975: plate 56).

Dingleya phymatodea (B.C. Zhang \& Minter) Trappe, Castellano \& Malajczuk - Fruit bodies up to $2.5 \mathrm{~cm}$ broad, subglobose, brown, with irregularly polygonal warts up to $1 \mathrm{~mm}$ broad and $0.4 \mathrm{~mm}$ tall. Gleba yellowish brown at maturity, with chambers lined with a hymenium of paraphyses, asci and spores. Spores globose, pale yellow, 17-22 (-25) $\mu \mathrm{m}$ broad excluding the ornamentation of crowded, rounded warts $1-5 \mu \mathrm{m}$ broad. Illustrations - Zhang \& Minter (1988: 53, 55); Trappe et al. (1992: 602).

Dingleya tectiascus Trappe, Castellano \& Malajczuk - Fruit bodies small, subglobose, pale brown, with irregular, flattened warts up to $0.8 \mathrm{~mm}$ broad. Gleba solid, brown with labyrinthine chambers lined with a hymenium. Spores globose, $18-12 \mu \mathrm{m}$ broad excluding the ornamentation of crowded, hyaline warts up to $4 \mu \mathrm{m}$ broad. Differs from other species in the genus because the paraphyses exceed the asci to form a rightly interwoven epithelium that covers the ascus tips. Illustrations - Trappe et al. (1992: 600).

Gymnohydnotrya echinulata (G.W. Beaton) B.C. Zhang \& MinterFruit bodies white to greyish olive, up to $2 \mathrm{~cm}$ broad, convoluted, with one to several chambers, the cylindrical asci in a hymenium covering the sporocarp surface but not lining the chambers. Spores $17-23 \times 12-16 \mu \mathrm{m}$ excluding the ornamentation of irregular spines up to $4.5 \times 2 \mu \mathrm{m}$ joined in places by an arch-like reticulum. Illustrations - Beaton \& Weste (1978: 165), as Sphaerozone echinulatum; Zhang \& Minter (1989: 194).

Hydnoplicata convoluta (McAlpine) Trappe \& Claridge - Among the more widely distributed sequestrate species in temperate Australian forests, its much convoluted and infolded, glabrous, white to pale greyish yellow fruit bodies are $1-4 \mathrm{~cm}$ broad. In youth they may have a single chamber with a small opening, but as they mature they fold inwardly so much as to form a series of large, open, labyrinthine chambers. Asci turn blue in iodine solution. Illustrations - McAlpine \& Rodway (1896: figs 11-14), as Hydnocystis convoluta; Gilkey (1954: 786), as Hydnoplicata whitei;
Beaton \& Weste (1982b: 457) and Bougher \& Syme (1998: 103), both Peziza whitei; Trappe \& Claridge (2006: 34).

Labyrinthomyces varius (Rodway) Trappe - Fruit bodies almost perfectly globose, about the same colour as dark soil and often with much soil clinging to their tomentose surfaces. Cut in half, the firm gleba at maturity presents an attractive pattern of brown, broad, labyrinthine chambers separated by broad veins of white, sterile tissue. Asci borne in a hymenium that lines the chambers and are more than twice as long as the paraphyses. Spores globose, up to 25 $\mu \mathrm{m}$ broad, ornamented with broad, rounded warts. Illustrations -Boedijn (1939: 239), White (1956: plate 11) and Beaton \& Weste (1977: 244), all as Labyrinthomyces steenisiz; Trappe (1979: 309); Trappe et al. (1992: 600).

\section{BASIDIOMYCOTA}

\section{[Agaricales]}

Amarrendia lignicolor (G.W. Beaton, Pegler \& T.W.K. Young) Bougher \& T. Lebel - Fruit bodies up to $1.5 \mathrm{~cm}$ broad, pale brown to ivory, in age with some reddish stains. Gleba chambered, pale pinkish brown to greyish orange. Spores smooth, 6-8 x 4.5-6 (6.5) $\mu \mathrm{m}$, hyaline. Illustrations - Beaton et al. (1985c: 579, 585) as Alpova lignicolor; Bougher \& Lebel (2002: 521).

Dermocybe globuliformis (Bougher) Bougher \& Trappe - Although not strictly sequestrate, this diminutive species is completely hypogeous. Pileus rarely exceeds $2 \mathrm{~cm}$ broad and is bright yellow, as are the veil, stipe, and immature lamellae. Stipe reduced to less than $7 \mathrm{~mm}$ long, never lifting the pileus out of the soil. As spores mature, they colour the lamellae bright cinnamon and are discharged onto the persistent, submembranous veil. Illustrations - Bougher \& Malajczuk (1986: 302, 303) and Bougher \& Syme (1998: 250, 251), both as Cortinarius globuliformis.

Descomyces albellus (Massee \& Rodway) Bougher \& Castellano The white, felty peridium of this small, ubiquitous fungus has a patchy to abundant overlay of veil-like yellow tufts and fibrils, under which is a pellis of interwoven to appressed hyphae with scattered, sphaerocyst-like cells. Gleba white in youth, dark brown by maturity. It abounds in many forest types, including disturbed habitats, and has been introduced around the world as a hitchhiker on roots of introduced eucalypt seedlings. Illustrations - Cunningham (1934: 169 and 1944: plate xxxiii), as Hymenogaster albellus; Bougher \& Castellano (1993: 278, 281).

Descomyces albus (Klotzsch) Bougher \& Castellano-Differentiated from $D$. albellus by having a pellis of inflated cells so abundant as to form an epithelium. Otherwise, the two are indistinguishable and have often been confused by past workers. Both are similarly abundant and widely distributed. Illustrations - Beaton et al. (1985a: 191, 202-203), as Hymenogaster albus; Bougher \& Syme (1998: 268, 269).

Descomyces giachinii Trappe, V. L. Oliveira, Castellano \& Claridge - Species of Descomyces fairly much all look alike macroscopically. This species differs from the others in its combination of a lack of an epithelium of large, rounded cells and the presence of cirriform spores 14-20 (-23) x (8-) 9-11 (-13.5) $\mu \mathrm{m}$ ornamented with a small-meshed reticulum up to $1 \mu \mathrm{m}$ tall. Illustrations - Giachini et al. (2000: 1172).

Descomyces new species $\boldsymbol{A}$ - Macroscopically similar to other Descomyces species, it differs from $D$. giachinit in having an ornamentation of warts, lines and a coarse, partial, meandering to alveolate reticulum $1-1.5(-3) \mu \mathrm{m}$ tall. 
Hydnangium cameum Wallr. - The pink peridium and gleba are distinctive. A columella may be lacking, poorly developed, or occasionally conspicuous, but an easily detachable, white, basal pad is nearly always present. Spores globose to subglobose, hyaline, 12-18 x 11-17 $\mu \mathrm{m}$ excluding the ornamentation of conical spines. One of the more common and widespread eucalypt mycorrhizal fungi, it has been introduced around the world where eucalypt seedlings have been transported from Australia. Illustrations - Beaton et al. (1984a: 501, 503); Cunningham (1944: plate xxxiii); Grgurinovic (1997: 295); Bougher \& Syme (1998: 197).

Hydnangium new species $\boldsymbol{A}$-. Differs from $H$. carneum by its much smaller, globose spores, $6-10 \mu \mathrm{m}$ broad. The fruit bodies are up to $22 \mathrm{~mm}$ broad, with a white to pink or brownish pink peridium. The pink to pinkish brown gleba may or may not have a prominent basal pad, but no columella has been observed so far. Glebal chambers can be up to $5 \times 1.5 \mathrm{~mm}$, the longest radiating from the basal attachment or pad.

Hymenogaster maidenii Rodway - This species will be transferred to Descomyces. It macroscopically resembles other Descomyces species but differs microscopically in lacking an epithelium and having spores $13-16 \times 9-11 \mu \mathrm{m}$ excluding the ornamentation of a partial to complete, finely labyrinthine reticulum $0.2-0.6 \mu \mathrm{m}$ tall.

Hymenogaster nanus Massee \& Rodway - This species needs transfer to Protoglossum. Fruit bodies up to $3 \mathrm{~cm}$ broad, greyish brown, with a thick, gelatinous pellicle. Gleba brown, with a usually well developed sterile base. Spores brown and mostly ellipsoid, (13-) $15-16 \times 8-9.5 \mu \mathrm{m}$ excluding the ornamentation of warts $\pm 1 \mu \mathrm{m}$. tall. Illustrations - Cunningham (1944: plate xxxiii).

Hysterogaster fusisporus (Massee \& Rodway) G.W. Beaton, Pegler \& T.W.K. Young. - Fruit bodies up to $2 \mathrm{~cm}$ broad, white to yellowish white, felty. Gleba ivory in youth, becoming brown by maturity. Spores smooth, dextrinoid, and fusoid, $15-22 \times 7-8 \mu \mathrm{m}$. Illustrations - Dodge \& Zeller (1934: plate 18), and Cunningham (1944: plate xxxiii), both as Hymenogaster fusisporus; Beaton et al. (1985c: 589,593$)$

Hysterogaster tasmanicus (G.H. Cunn.) G.W. Beaton, Pegler \& T.W.K. Young - Fruit bodies dirty white, smooth, up to $12 \mathrm{~mm}$ broad. Gleba brownish yellow with a basal projection. Spores broadly fusoid, moderately dextrinoid, 11-13 x 6.5-9 $\mu \mathrm{m}$, shorter and broader than those of $H$. fusisporus. Illustrations - Cunningham (1934: 169 and 1944: plate xxxiii), as Hymenogaster tasmanicus; Beaton et al. (1985c: 589, 593).

Protoglossum niphophilum Trappe \& Claridge - Peridiumgelatinousviscid and white with a violet to lilaceous tinge or violet to lilac overall, up to $800 \mu \mathrm{m}$ thick. Gleba loculate and at maturity rusty brown from massed spores. Odour slightly of radish. Spores 12-15 $(-16) \times 6-8(-9) \mu \mathrm{m}$ excluding the ornamentation of uncrowded minute warts and ridges. Illustrations - Trappe \& Claridge (2003: $30,31)$.

Protoglossum violaceum (Massee \& Rodway) T.W. May - Fruit bodies up to $3 \mathrm{~cm}$ broad, the peridium with a thick, gelatinous, bright greyish violet pellicle. Gleba cinnamon, loculate with a small to prominent, white sterile base but little or no columella. Spores broadly ellipsoid to obovoid, $8.5-10(-11) \times 6-7 \mu \mathrm{m}$ excluding the ornamentation of fine warts. Illustrations - Cunningham (1944: plate xxxiii), as Gymnoglossum violaceum; Beaton etal. (1985a: 187, 201), as Hymenogaster violaceus.
Protoglossum viscidum (Massee \& Rodway) T.W. May_-Fruit bodies subglobose to slightly turbinate. Peridium thick, gelatinous-viscid, brownish orange to orange brown. The brown gleba has relatively large chambers. This species has been subject to considerable confusion in the past, having been synonymised with $P$. luteum by various workers. The ellipsoid spores of $P$. viscidum, however, are 14-18 x 9-12 $\mu \mathrm{m}$, substantially larger than those of the globose-spored $P$. luteum. Except for the illustration cited below, other past illustrations purported to be $P$. viscidum are $P$. luteum. Illustrations - Bougher \& Castellano (1993: 278), as Cortinomyces viscidus.

Protoglossum new species $A$ - Fruit bodies orange brown to dark reddish brown, smooth, with a thick, glutinous-warty pellicle and musty odour. Gleba deep cinnamon, loculate, with an inconspicuous to prominent, white, basal pad. Spores brownish yellow, ellipsoid, 10-14 (-16) x 7-9 $1 \mathrm{~m}$ excluding the ornamentation of amorphous, ill defined warts and ridges $0.5-1 \mu \mathrm{m}$ tall.

Protoglossum new species B - Fruit bodies canary yellow, smooth, with a thick, gelatinous pellicle. Gleba deep cinnamon, with a basal pad sometimes elongated into a short columella. Spores brown, ellipsoid to broadly ellipsoid, $10-15 \times 7.5-10 \mu \mathrm{m}$, ornamented with crowded warts $\pm 0.2 \mu \mathrm{m}$ long and broad.

Protoglossum new species $C$ - Fruit bodies up to $2.5 \mathrm{~cm}$ broad, lilac, with a thick, gelatinous pellicle. Gleba loculate, cinnamon from the spore mass, the trama with hyphae up to 20 or more $\mu \mathrm{m}$ broad; basal pad absent or inconspicuous, columella lacking. Spores light cinnamon, $10-12 \times 5.5-6(-7) \mu \mathrm{m}$ excluding the ornamentation of fine warts and ridges $\pm 0.5 \mu \mathrm{m}$ tall. It differs from $R$. violaceum by its broad tramal hyphae and spores with a larger length:width ratio.

Protoglossum new species $D$ - Peridium orange brown to reddish brown as dried, with a thick, gelatinous pellicle. Gleba dark cinnamon with an inconspicuous, yellowish basal pad. Spores pale brownish yellow, ellipsoid, 11-14 x 7-9 $\mu \mathrm{m}$ excluding the hyaline ornamentation of minute warts and wrinkles $0.2-0.5(-1)$ $\mu \mathrm{m}$ tall.

Quadrispora oblongispora (G. Beaton, Pegler \& T.W.K. Young) Bougher \& Castellano - Peridium gelatinous-viscid, thick, dull yellow to orange yellow. At maturity the dark brown gleba has chambers up to $1.5 \mathrm{~mm}$ broad. This genus differs from Protoglossum by having spores that cling together in tetrads after discharge from the basidia. Illustrations - Beaton et al. (1985a: 187, 202), as Hymenogaster oblongisporus; Bougher \& Castellano (1993: 286).

Thaxterogaster new species $A$ - Fruit bodies up to $11 \times 18 \mathrm{~mm}$, in youth totally enclosed in a thick, white veil that breaks up on the upper surface of specimens as they expand to expose a pale, brownish grey peridium. The cinnamon gleba has chambers that radiate from the contorted stipe, which is truncate or percurrent as a columella; the thick, peronate veil persists on the stipe and attaches to the margin of the peridium. The odour is faintly of chlorine.

Thaxterogaster new species $B-\mathrm{Up}$ to $16 \times 13 \mathrm{~mm}$, this species is subconic to globose with a light yellowish brown peridium supporting silvery parches of veil. It features a robust, percurrent stipe-columella $4-5 \mathrm{~mm}$ broad and a marginate base $8-12 \mathrm{~mm}$ broad; the margin of the gleba is pressed against the upper side of the basal stipe bulb and attached to or slightly seceded from it by a thick, fibrillose veil. The spores are minutely punctate.

Thaxterogaster new species $C$ - Up to $16 \times 18 \mathrm{~mm}$, this species has a silky-shining, violet peridium, the margin of which is confluent 
with the stipe. The chambered gleba has a cylindric stipe-columella up to $3 \mathrm{~mm}$ broad with yellowish white to violet flesh. The brownish spores are ellipsoid, $8-10 \times 6-8 \mu \mathrm{m}$, excluding the ornamentation of warts $0.2-0.5 \mu \mathrm{m}$ tall and broad.

Timgrovea reticulata (G.H. Cunn.) Bougher \& Castellano - The small fruit bodies are dirty white mottled with brown and yellow patches. The gleba is rust brown at maturity, its chambers are up to 1 $\mathrm{mm}$ broad, and it has a small, pale basal pad but no columella. The spores are ornamented with reticulum ridges up to $2 \mu \mathrm{m}$ tall and 1-2 $\mu \mathrm{m}$ broad. Illustrations - Cunningham (1944: plate xxxiii), as Hymenogaster reticulatus; Bougher \& Castellano (1993: 289).

New genus $A$ new species $A$ - Attractive tich violet, felty-smooth, $\mathrm{dry}$, fruit bodies up to $2.5 \mathrm{~cm}$ broad. Gleba chambered, a rich coffee colour with a violet basal pad or short columella, or the last two structures often lacking. Spores ellipsoid, 7.5-10 x 6-7 $\mu \mathrm{m}$ excluding the ornamentation of warts $0.1-1 \mu \mathrm{m}$ tall.

New genus $A$ new species $B$ - Fruit bodies small, ellipsoid, dirty white, dry, the thick peridium enclosing a dark cinnamon gleba. Spores ellipsoid to obovoid, $11-15 \times 8-10 \mu \mathrm{m}$, dark reddish brown, ornamented with irregular warts and longitudinally aligned ridges up to $1 \mu \mathrm{m}$ tall, $3 \mu \mathrm{m}$ broad and $6 \mu \mathrm{m}$ long.

New genus $A$ levisporus - This new combination will be based on Hymenogaster levisporus Massee \& Rodway. The small, young, silvery white fruit bodies stand out brightly when raked from the soil but become brownish white towards full maturity. Fruit bodies up to $3 \mathrm{~cm}$ broad with a chambered, cinnamon coloured gleba typically with a conical, white to brownish white basal pad that varies greatly from barely noticeable to prominent, sometimes occupying half or more of the gleba or narrowing to a percurrent columella. Spores brown with warts so minute as to be easily overlooked at magnifications of less than $\times 1000$. Illustrations - Cunningham (1944: plate xxxiii) and Dodge \& Zeller (1934: plate 18), both as Hymenogaster levisporus; Beaton et al. (1985a: 170, 199), as Thaxterogaster levisports.

New genus $B$ aureus - This new combination will be based on Hymenogaster aureus Rodway. Fruit bodies up to $2 \mathrm{~cm}$ broad, bright yellow, fading to pale yellow by full maturity. Gleba whice in youth, becoming pinkish brown at maturity. Spores smooth, fusoid or irregular, 9-19 × 5-8 $\mu \mathrm{m}$, similar to spores of Hysterogaster but not dextrinoid. Illustrations - Cunningham (1944: plate xxxiii) and Beaton et al. (1985a: 183), both as Hymenogaster aureus.

New genus C ochraceum - Based on Secotium ochraceum Rodway, this collection seems not to fit in any known genus, but Rodway's specimen is not in good enough condition to be well described or serve as a type collection. 1t may belong in the Bolbitiaceae, close to Setchelliogaster.

\section{[Atheliales]}

Stephanospora flava (Rodway) G.W. Beaton, Pegler \& T.W.K. Young - Small, bright yellow, often lumpy and irregular, its gleba is dull greyish olive to greyish brown. The hyaline, ellipsoid to subglobose spores are 10-12 $\mu \mathrm{m}$ broad excluding the ornamentation of crests and spines and a crown-like collar a round the sterigmal attach ment. Related to the poroid genus Lindtneria, it occurs in wet forests and is one of the few sequestrate species of rain forests. Illustrations Cunningham (1944: plate xxxiii) and Cribb (1958: 253), both as Octaviania flava; Singer \& Smith (1960: 107), as Octavianina flava; Beaton et al. (1985c: 595, 596); Claridge \& May (1994: 255).
Stephanospora new species $A$ - Resembles $S$. flava but with larger, more globose spores $10-15 \mu \mathrm{m}$ broad excluding the ornamentation of tapering spines and wedges $1-4 \mu \mathrm{m}$ tall and a distinct basal collar encircling the sterigmal attachment; the spores cling together in fours.

\section{[Boletales]}

Gymnopaxillus vestitus Claridge, Trappe \& Castellano - Up to 2 $\mathrm{cm}$ broad, irregular and lumpy, sometimes confluent in rows. The white, cottony peridium is often patchy. The chambered, bright rust to cinnamon coloured gleba has an irregular, columnar to dendroid columella, but that may be lacking in some specimens. Spores are smooth, ellipsoid to narrowly ellipsoid, vivid golden yellow. Illustrations — Claridge et al. (2001: 277).

Hydnangium clelandii Rodway - This species will be transferred to the genus Horakiella. Up to $2 \mathrm{~cm}$ broad, tomentose in patches, dingy yellow, in cross section reddening where cut. Gleba firm with locules packed with a dark brown spore mass at maturity. Spores pale brown, globose to subglobose, ellipsoid, obovoid or subangular, $25-30(-40) \times 30-35(-40) \mu \mathrm{m}$, with 2 wall layers, the surface wrinkled or with an obscure reticulum $\pm 0.1 \mu \mathrm{m}$ tall. Illustrations - Cunningham (1944: plate xxxiii), as Octaviania clelandii.

Octaviania new species $A$ - Rarely more than one cm broad, the fruit bodies are dirty white in youth but later darken to yellowish olive or olive, with brown to black or sometimes blue stains. The labyrinthiform glebal chambers filled with a gelatinous suspension of cinnamon brown, globose spores ornamented with cones and spines $2-3 \mu \mathrm{m}$ tall.

Scleroderma paradoxum G.W. Beaton - The completely hypogeous fruit bodies are 6-25 $\mathrm{mm}$ broad, subglobose to flattened or irregular, initially sordid cream colour to sordid yellow but at maturity dark brown. The gleba is black and firm at early maturity but becomes a powdery spore mass at maturity. The odour is faint in youth, becoming musty, fishy or like cat urine by maturity. Illustrations - Beaton \& Weste (1982a: 42, 43).

New genus $\boldsymbol{D}$ - This new genus will be based on Chamonixia vittatispora G.W. Beaton, Pegler \& T.W.K. Young. Peridium initially white with some blue tinges, at senescence becoming greyish orange. The brown gleba has a small, whitish basal pad. Spores pale brown at maturity, smooth, bilaterally symmetrical, in transverse section subangular with 5 or 6 longitudinal facets. It is a species complex that needs a new genus. Illustrations - Beaton et al. (1985c: 583, 585).

New genus E new species $A$ - The small fruit bodies are brownish white with a pale gleba containing smooth, colourless, ellipsoid to narrowly ellipsoid spores $6-8 \times 3-4 \mu \mathrm{m}$ with a length:width ratio of $1.6-2.7$.

New genus E new species $B$ - Differs from new genus $E$ new species $A$ by its ellipsoid to broadly ellipsoid spores with a length:width ratio of $1.4-1.8$.

\section{[Gomphales]}

Gautieria albida (Massee \& Rodway) G.H. Cunn. sensu Zeller \& C.W. Dodge - Fruit bodies with a white peridium, a prominent basal rhizomorph, and a loculate, orange yellowgleba with a dendroid columella. Spores mostly ellipsoid, 17-26 x 13-17 $\mu \mathrm{m}$, including the ornamentation of $10-12$, frequently forking, longitudinal, humped ridges $1-5 \mu \mathrm{m}$ tall and $2-4.5 \mu \mathrm{m}$ broad. Cunningham's (1944) and Beaton's et al. (1985a) descriptions and illustrations for 
G. albida are actually that of an undetermined, probably undescribed Austrogautieria species.

Gautieria new species $A$ - Fruit bodies with a continuous to patchy, yellowish white to pale yellow, fibrillose peridium. The brown gleba has a grey, cartilaginous basal pad that may lack a columella or extend as an inconspicuous one. Spores mostly ellipsoid, (12--) 18-23 x 12-6 $4 \mathrm{~m}$, excluding the ornamentation of $7-10$, rounded, longitudinal ridges up to $5 \mu \mathrm{m}$ tall that greatly exceed the spore apex but do not converge there.

\section{[Hysterangiales]}

Austrogautieria chlorospora E.L. Stewart \& Trappe - The small fruit bodies are brown to light dull reddish brown. The gleba is soft and strikingly yellowish green to dark green from the massed, yellowish green spores ornamented with 8-13 hyaline, longitudinal, sinuate, forking, acute-margined ridges up to $2.5 \mu \mathrm{m}$ tall. Originally thought to be related to Gautieria in the Gomphales, Austrogautieria has since been found by molecular phylogenetic techniques to belong to the Hysterangiales (Hosaka et al. 2006). Illustrations - Stewart \& Trappe (1985: 678).

Austrogatutieria clelandii E.L. Stewart \& Trappe-Small and smooth, with a readily separable, brownish white peridium up to $1 \mathrm{~mm}$ thick, this species has a rubbery, moderate brown to dark brown gleba with a narrow, translucent, dendroid columella. Spores 16-21 x 12-17 $\mu$ m excluding the ornamentation of 8-11 longitudinal, smooth, acute-margined ridges up to $3 \mu \mathrm{m}$ tall and $1-2.5 \mu \mathrm{m}$ broad. The peridium has a prominent layer of pseudoparenchyma. Illustrations - Cunningham (1944: plate xxxiv), as Gautieria clelandii; Stewart \& Trappe (1985: 682).

Austrogautieria costata E.L. Stewart \& Trappe - Macroscopically, this species resembles $A$. clelandii. However, its spores are smaller (12-16 x 9-12 $\mu \mathrm{m}$ excluding the ornamentation of 8-12 longitudinal ridges up to $3 \mu \mathrm{m}$ tall and $1-2.5 \mu \mathrm{m}$ broad) than those of the latter, and its peridium is of interwoven hyphae rather than of inflated cells. Illustrations - Cunningham (1944: plate xxxiv) and Beaton et al. (1985a: 197, 203), both as Gautieria costata; Stewart \& Trappe (1985: 680); .

Austrogautieria new species $A$ - This species resembles A. clelandii. However, its sporeornamentation differs strikingly from $A$. clelandii, being irregular, longitudinal patches and ridges $1-1.5 \mu \mathrm{m}$ tall and 2-3 $\mu \mathrm{m}$ broad, with roughened and channelled edges and a crested, irregular, obtuse to subangular margin. Many spores produce germ tubes in the fruit bodies.

Austrogautieria new species $B$ - Fruit bodies up to $3 \times 5 \mathrm{~cm}$, with a brown peridium and gleba, lacking a columella. Spores fusoid to narrowly citriform with a cupped sterigmal appendage and a distinctive apical, cylindric, obtuse prolongation 2-4 $\times 2 \mu \mathrm{m}$. The spores are ornamented with 6-9 longitudinal, forking ridges $1-3 \mu \mathrm{m}$ tall and with acute margins.

Castoreum radicatum Cooke \& Massee - Fruit bodies with a stout, root-like basal rhizomorph, the peridium smooth and elastic when fresh, hard when dry, brown, 2-2.5 mm thick, 3-layered: outer layer up to $400 \mu \mathrm{m}$ thick; middle layer up to $750 \mu \mathrm{m}$ thick, of loosely interwoven hyphae and mycorrhizae; inner layer up to $2 \mathrm{~mm}$ thick, of highly refractive hyphae. Gleba a greyish orange, powdery spore mass with interspersed capillitial hyphae. Illustrations - Cunningham (1944: plate xxxv); Beaton \& Weste (1984: 668), Grgurinovic (1997: 605).
Chondrogaster new species A - Fruit bodies small, subglobose to globose, enclosed in a sheath of white mycelium and mycorrhizae. Gleba dark yellowish olive. The spores are smooth, hyaline, ellipsoid, 13-14 x 4-5 $\mu \mathrm{m}$, with a patchy, irregular utricle and a remnant of the sterigma attached at the base.

Chondrogaster new species B - Fruit bodies small, enclosed in a mix of whitish to pinkish mycelium and mycorrhizae. The gleba is pale olive. The hyaline spores are broadly ellipsoid to broadly fusoid, 10-12 x 5-6 $\mu \mathrm{m}$, and enclosed in a lumpy, coarse, appressed utricle. The squat, broad spores with their coarse utricle differentiate this species from new species $A$.

Hysterangium affine Massee \& Rodway - Fruit bodies up to $2 \mathrm{~cm}$ broad with one or more stout, basal rhizomorphs. The smooth, white peridium stains rose where bruised and readily separates from the green, cartilaginous gleba. $H$. affine has been variously interpreted in the past, but the type collection has ellipsoid to oblong spores $11-13 \times 3.5-5 \mu \mathrm{m}$ enclosed in an irregularly inflated utricle and a peridium of hyaline, polyhedral cells $50-75 \times 30-40 \mu \mathrm{m}$. Illustrations - Rodway (1912: plate III, fig. 9); Zeller \& Dodge (1929: plates 2-3); Cunningham (1944: plate xxxiv); Beaton $e$ al. (1985b: 439, 441).

Hysterangium gardneri E. Fischer - The tomentose to felty, white to pale brown peridium has much adherent soil and organic debris, stains pink where bruised or cut, and does not separate readily from the carrilaginous, green to dark green gleba. Gleba with a narrow, dendroid, translucent columella. Rhizomorphs are adpressed overall and the same colour as the peridium. The species was originally described from California, where it was collected under introduced eucalypts. Illustrations - Fischer (1908: plate 6, fig. 19).

Hysterangium inflatum Rodway - Up to $2.5 \mathrm{~cm}$ broad, the fruit bodies have a mostly tomentose, dull white peridium that stains pale brown to pale reddish brown when exposed. Gleba at maturity dark olive to nearly black with a dendroid, narrow, translucent columella. The narrowly ellipsoid spores are enclosed in a utricle laterally inflated up to $2.5 \mu \mathrm{m}$. Illustrations - Cunningham (1944: plate xxxiv); Beaton et al. (1985b: 437, 441).

Hysterangium new species $A$ - Up to $16 \mathrm{~mm}$ broad and subglobose to lobed or irregular, the smooth fruit bodies are white and stain pink to red where bruised. The readily separable peridium is up to 1 mm thick. Gleba dark greyish green, cartilaginous, with a dendroid columella. The smooth spores are $11-13 \times 5-6 \mu \mathrm{m}$ and their lack of a utricle is unusual for this genus.

Mesophellia glauca (Cooke \& Massee) D. A. Reid - The dirt encrusted spheres, often fused together in 2's and 3's, resemble globose soil clods and a have a 3-layered peridium: a thin, brittle outer layer, a thick, white, soft, middle layer that incorporates masses of mycorrhizal rootlets, and a thin, leathery or rubbery inner layer. The centre consists of a core of rubbery tissue attached to the inner peridial layer by minute to robust columns, in between which is a powdery, greyish olive mass of spores. Animals remove the peridium and most of the spores to get at the inner core, which they eagerly eat. The spores are thus dispersed by air movement, by dusting the fur, whiskers and paws of the animals, or by being accidentally ingested with the core. Illustrations - Beaton \& Weste (1983: 210, 211, 213); Claridge \& May (1994: 258); Trappe et al. (1996: 786, 790); Grgurinovic (1997: 602); Claridge \& Trappe (2004: 937).

Nothocastoreum cretaceum (Lloyd) G. W. Beaton - Small, orangebrown and subglobose to ellipsoid, this species has a thin, brittle 
peridium that ruptures at the top in an irregular stellate pattern to expose the grey, powdery spore mass. Many fruit bodies often cluster just under the soil surface. When animals such as wallabies scratch them out to eat, the spore powder is released to the air. Illustrations - Lloyd (1922: fig. 1978), as Diploderma cretaceum; Cunningham (1932: plate xi and 1944: plates xvii, xxxv), as Castoreum cretaceum; Beaton \& Weste (1984: 667); Grgurinovic (1997: 605).

New genus $F$ neglectum - This new genus will be based on Hysterangium neglectum Massee \& Rodway. The subglobose to flattened fruit bodies are white with brown stains and fibrillose. Peridium separable, up to $1 \mathrm{~mm}$ thick. The dark brown, gelatinous gleba has a grey, translucent, dendroid columella. The smooth, thickwalled spores are 14-19 (-21) $\mu \mathrm{m}$ with an amorphous but distinct utricle and are agglutinated together in bunches. Illustrations Cunningham (1944: plate xxxiv), as Hysterangium neglectum.

\section{[Russulales]}

Arcangeliella australiensis (Berk. \& Broome) C. W. Dodge - One of several species in the "smooth, orange species complex" of small, Australian species with whey-like to milky latex, it differs from the others by its globose to subglobose spores $6-7(-9) \mu \mathrm{m}$ broad, ornamented with a fine, amyloid reticulum $0.2-0.5 \mu \mathrm{m}$ tall and a pileipellis of appressed to emergent hyphae with only occasional inflated cells and rare dermatocystidia. The gleba is pale orangeyellow to pale orange. It has been misinterpreted by past workers such as Beaton et al. (1984b); our examination of the holotype showed it to be an earlier name for Zelleromyces corkii Trappe \& Claridge. Illustrations - Trappe \& Claridge (2003: 30, 31), as Zelleromyces corkit.

Arcangeliella claridgei (Trappe) Trappe \& Claridge - Another member of the "smooth, orange species complex", A claridgei differs from the others by its globose to subglobose spores $6-9 \mu \mathrm{m}$ broad ornamented with amyloid ridges $0.2-1 \mu \mathrm{m}$ tall in a zebroid pattern and its pileipellis an epithelium of inflated cells. Illustrations Trappe \& Claridge (2003: 30,31), as Zelleromyces claridgei.

Arcangeliella daucina (G.W. Beaton, Pegler \& T.W.K. Young) J.M. Vidal - Another member of the smooth, orange species complex that differs from the others by its globose spores $8-10.5 \mu \mathrm{m}$ broad ornamented with a coarse, strongly amyloid, complete reticulum up to $2.5 \mu \mathrm{m}$ tall and a dark orange to brownish orange peridium with an epithelium of inflated cells $10-20 \mu \mathrm{m}$ broad. Illustrations — Beaton et al. (1984b: 685) and Bougher \& Syme (1998: 136, 137), both as Zelleromyces daucinus.

Arcangeliella new species $\boldsymbol{A}$ - Still another member of the smooth, orange species complex, differing from the others by its globose to subglobose spores $6-7(-8) \mu \mathrm{m}$ broad excluding the ornamentation of a fine reticulum $0.2-1.5 \mu \mathrm{m}$ tall and a moderate orange peridium with an epithelium of inflated cells $5-15 \mu \mathrm{m}$ broad.

Arcangeliella new species $B$ - Finally, another member of the smooth, orange species complex, differing from the others by its globose spores $7-9(-10) \mu \mathrm{m}$ broad ornamented with amyloid ridges $\pm 0.5 \mu \mathrm{m}$ tall in a zebroid pattern and its brownish orange to orange brown pileipellis of interwoven hyphae surmounted by a tangled turf of hyphal tips.

Cystangium flavovirens T. Lebel - The olive-yellow peridium, ivory to yellow, loculate gleba and often robust stipe are distinctive. The peridium is an epithelium up to $110 \mu \mathrm{m}$ thick, composed of $5-8$ tiers of rounded cells $6-11 \mu \mathrm{m}$ broad overlain by a patchy layer of upright hyphal tips that become repent with age. The ellipsoid to subglobose spores are $8-9.5 \times 7.5-8.5 \mu \mathrm{m}$ excluding the ornamentation of amyloid warts often joined in groups of $2-7$ by irregular ridges $<0.5 \mu \mathrm{m}$ tall. Illustrations - Lebel $(2003 \mathrm{a}: 378,379)$.

Cystangium megasporum (Rodway) T. Lebel \& Castellano - Peridium smooth to irregularly roughened or pubescent, whitish to pale cream colour, sometimes becoming brown with age. Gleba cream colour, with small, irregular locules. Columella and stipe missing. Spores globose, ornamented with coarse, crowded spines so strongly amyloid that they render the spore nearly opaque. Illustrations Cunningham (1944: plate xxxiii), as Octaviania megaspora; Lebel \& Castellano (2002: 336, 337).

Cystangium rodwayi (Massee) A.H. Sm. - Fruit bodies up to 3 $\mathrm{cm}$ broad, whitish, pruinose to finely tomentose. Gleba with a well defined, white, usually curved stipe-columella $2-3 \mathrm{~mm}$ broad. The spores are globose, $7-10 \mu \mathrm{m}$ broad excluding the ornamentation of low warts connected to form short, branched, irregular ridges in a partial reticulum. Illustrations - Cunningham (1944: plate xxxiv), as Secotium rodwayi; Lebel and Castellano (2002: 350).

Cystangium seminudum (Massee \& Rodway) T. Lebel \& Castellano - Fruit bodies small, white to cream colour or brownish, subglobose, pubescent overall or in patches, soft to firm. Gleba white, sometimes with brown patches, columella rudimentary or absent. The hymenium contains very large cystidia, which extend well beyond the basidia. The globose spores are ornamented with strongly amyloid spines. Illustrations - Cunningham (1944: plate xxxiii), as Octaviania seminuda; Pegler \& Young (1979: 376) and Beaton et al. (1984b: 679), both as Gymnomyces seminudus; Lebel \& Castellano (2002: 339, 340, 341).

Cystangium sessile (Massee \& Rodway) Singer \& A.H. Smith - Fruit bodies $2-4 \mathrm{~cm}$ broad, white, sometimes staining slightly pink when exposed, glabrous, with a white, usually percurrent stipe-columella. Gleba sublamellate to chambered, often exposed around the stipe. The hymenium contains abundant, very large cystidia. Spores subglobose, ornamented with irregularly amyloid spines and cones. Illustrations -- Cunningham (1944: plates ix, xxxiv), as Secotium sessile; Pegler \& Young (1979:366); Beaton et al. (1984b: 673, 694); Lebel \& Trappe (2000: 1192).

Cystangium sparsum T. Lebel - Fruit bodies up to $2 \mathrm{~cm}$ broad, smooth or tugose at base, sordid white, becoming pale yellow mottled with brown. Gleba cream colour to pale tan, chambered. Stipe and columella absent or the latter represented as a basal pad or narrow, percurrent strand. Odour faintly of chlorine. Spores globose to subglobose, ornamented with sparse, amyloid warts isolated or clustered, $<0.5 \mu \mathrm{m}$ tall. Illustrations -- Lebel $(2003 \mathrm{a}: 389,390)$.

Gastrolactarius new species $A$ - This species resembles those of the "smooth, orange species complex" of Arcangeliella as seen from above, but unlike those it clearly has a straight to recurved stipe up to $5 \mathrm{~mm}$ long when viewed from below. The stipe emerges from a gelatinous, percurrent, orange columella. The brownish orange peridium has a patchy to continuous epithelium of rounded cells surmounted by a suprapellis of cystidia and tangled hyphae. Spores globose to subglobose, $7-10 \mu \mathrm{m}$ broad excluding the ornamentation of a reticulum $0.5-1.5 \mu \mathrm{m}$ tall.

Gymnomyces eburneus T. Lebel - This globose to subglobose species has a usually smooth, very white peridium that sometimes stains slightly brown when bruised. Gleba initially white, later becoming cream colour to pale yellow. Columella usually absent, but sometimes a narrow strand develops from the basal pad to the sporocarp apex. Odour faintly of radish at maturity. Illustrations — Lebel (2003b: 410, 411). 
Gymnomyces glared T. Lebel - Glarea is Latin for gravel: the fruit bodies resemble pebbles. Up to $22 \mathrm{~mm}$ broad, the fruit bodies have a smooth, white peridium that soon becomes brownish mottled with brown stains. Gleba initially ivory, soon developing brown stains. A stipe may be lacking or present but inconspicuous. The spores are globose to subglobose, $8.5-10 \times 8-10 \mu \mathrm{m}$ excluding the ornamentation of irregularly amyloid spines up to $2 \mu \mathrm{m}$ tall, isolated or clustered in groups of 3-4 or with some ridges $<1 \mu \mathrm{m}$ tall connecting the spines to form a partial reticulum. Illustrations — Lebel (2003b: 414, 415).

Gymnornyces pallidus Massee \& Rodway - Fruit bodies up to $2 \mathrm{~cm}$ broad, smooth but with patches of pubescence, with a yellowish brown peridium and a cream coloured to light brown gleba. The hymenium contains frequent, prominent, acicular cystidia. Spores globose to subglobose, $7-9(-10) \mu$ m excluding a low ornamentation of scattered warts and short lines; the sterigmal attachment is larger than for most Gymnomyces species (1-2 $\mu \mathrm{m}$ tall and broad) and on many spores is strongly amyloid or with heavy amyloid deposits at the base. Illustrations - Pegler \& Young (1979: 376); Lebel \& Trappe (2000: 1196, 1197); Lebel \& Castellano (2002: 338).

Gymnomycespterospermus T. Lebel - Up to $4 \mathrm{~cm}$ broad, this species has a smooth, dry, white peridium mottled with brown and an ivory to brownish gleba mottled dark brown in age. The globose spores are 9.5-13 $\mu \mathrm{m}$ broad and distinctive for their amyloid ornamentation of branched, ragged ridges that form a reticulum $2-4 \mu \mathrm{m}$ tall and $1 \mu \mathrm{m}$ thick. Illustrations - Lebel (2003b: 418, 419).

Gymnomyces westresii T. Lebel - Peridium dry and inicially pale yellow, later developing orange to brick red or brown streaks and patches while the underlying yellow colour deepens. Gleba pale yellow, sometimes with brown zones, with small locules. Illustrations — Lebel (2003b: 422, 423).

Hydnangium glabrum Rodway -- This species will be transferred to Arcangeliella as yet another member of the smooth, orange, species complex. It closely resembles $A$. australiensis but has spores 7-9 $(-10) \mu \mathrm{m}$ broad and lacks cystidia on the peridium. Illustrations - Cunningham (1944: plate xxxiii), as Octaviania glabra.

Leucogaster meridionalis G.W. Beaton, Pegler \& T.W.K. Young - This species is pure white outside and in. The gleba has round chambers up to $1 \mathrm{~mm}$ broad that, when fresh and moist, exude a sticky, white suspension of spores in a fluid derived from autolysis of basidia and possibly other cells. In old or dry specimens, the spore mass is dry and fills the locules. Illustrations - Beaton $e t a l$. (1985d: 830, 831).

Russula albidoflava T. Lebel - A sequestrate Russula, this species resembles $R$. rostraticystidia macroscopically, but its white peridium develops a yellowish tinge. Its spores are subglobose to broadly ellipsoid, 7.5-10 x 7-8.5 $\mu \mathrm{m}$ and ornamented with an amyloid, partial to almost complete reticulum of fine ridges and scattered, isolated warts, all $<0.5 \mu \mathrm{m}$ tall. Cystidia $25-31 \times 7-10 \mu \mathrm{m}$, clavate to cylindrical. Illustrations - Lebel \& Tonkin $(2007: 363$, 364).
Russula rostraticystidia $\mathrm{T}$. Lebel - The sequestrate fruit bodies are up to $25 \times 15 \mathrm{~mm}$, globose to flattened, the margin of the cap incurved to form an indented base, ivory-white and smooth but with fine, felty white patches and brownish stains. Gleba white, becoming ivory, with small, crowded chambers. Stipe-columella white with brown stains, up to $3 \mathrm{~mm}$ broad, percurrent. Spores globose to subglobose, $6-9 \mu \mathrm{m}$ broad, ornamented with an amyloid, partial to complete reticulum $<0.5 \mu \mathrm{m}$ tall. Cystidia $48-75(-100) \times 4-12.5$ $\mu \mathrm{m}$, ventricose to cylindrical and elongated rostrate. Illustrations - Lebel \& Tonkin (2007: 374, 375).

\section{GLOMEROMYCOTA}

\section{[Diversisporales]}

New genus $G$ pulvinatum - Molecular studies by Redecker $e t$ al. (2007) indicate that Glomus pulvinatum should be placed in a new genus. The small sporocarps are initially white from a usually well developed peridium that becomes brown in age. Gleba a mass of spores and hyphae without any organised structure. Spores mostly subglobose to globose, $65-105 \mu \mathrm{m}$ broad, hyaline to subhyaline, thin-walled, with a hyphal attachment $8-15 \mu \mathrm{m}$ broad that is closed by a septum. Illustrations - Thaxter (1922: plate 2), as Endogone pulvinata; Redecker et al. (2007: 38).

\section{[Glomerales]}

Glomus australe (Berk.) S.M. Berch \& Fortin - Fruit bodies firm, globose with a white to pale yellow or pale brown peridium and a fibrillose to felty surface. Gleba a mix of loose, white hyphae and large, dark brown, spherical spores easily visible with a hand lens. Spores up to $0.3 \mathrm{~mm}$ broad, with thick walls and a broad, attached hypha. Illustrations - Berch \& Fortin (1983: 2613), McGee \& Trappe (2002: 119).

Glomus microcarpum Tul. \& C. Tul. - Fruit bodies a firm mass of spores in a matrix of white hyphae enclosed in a white to brown peridium. The spores, borne on the tips of hyphae, are hyaline to pale yellow, globose to variously shaped and range from $25 \times 25$ to $55 \times 32 \mu \mathrm{m}$. Spore walls up to $7 \mu \mathrm{m}$ thick. Illustrations - Tulasne \& Tulasne (1851: plate 20), Bucholtz (1912: 192) and Thaxter (1922: plate 2), all as Endogone microcarpa.

\section{ZYGOMYCOTA}

\section{[Endogonales]}

Endogone neglecta Rodway - Fruit bodies mostly 3-6 mm broad, subglobose, pale, fleshy or almost waxy-floccose. Spores globose, $32-53 \mu \mathrm{m}$ broad, with two hyaline walls, the outermost being \pm 5 $\mu \mathrm{m}$ thick, the inner $\pm 2 \mu \mathrm{m}$ thick. No hyphal attachments to spores could be found in the holotype, the only extant collection of this species. However, occasional spores had what could be interpreted as attached but collapsed gametangia. The generic placement of this species remains tentative until new material is found. 